\title{
Behavioral response of South American sea lion Otaria flavescens to tourist disturbance during the breeding season
}

Respuesta conductual del lobo marino común Otaria flavescens a

la perturbación por turistas durante la época reproductiva

\author{
Guido Pavez ${ }^{1}$, Lily Muñoz ${ }^{1}$, Patricia Inostroza ${ }^{2}$ and Maritza Sepúlveda ${ }^{2,3}$ \\ ${ }^{1}$ Facultad de Ciencias del Mar y de Recursos Naturales, Universidad de Valparaíso, Av. Borgoño 16344, Montemar, Viña del Mar, Chile \\ ${ }^{2}$ Centro de Investigación Eutropia, Ahumada 131, oficina 501, Santiago, Chile \\ ${ }^{3}$ Centro de Investigación y Gestión de los Recursos Naturales (CIGREN), Facultad de Ciencias, Universidad de Valparaíso, Av. Gran \\ Bretaña 1111, Playa Ancha, Valparaíso, Chile.maritza.sepulveda@uv.cl
}

\begin{abstract}
Resumen.- Los pinípedos muestran una alta predictibilidad en su distribución, tanto espacial como temporal, y tienden a congregarse en parches, lo que permite un fácil acceso de turistas. Sin embargo, la presencia de dichos turistas puede generar un impacto negativo sobre los animales. El objetivo de este estudio fue evaluar, por primera vez en Chile, el efecto del ecoturismo sobre el comportamiento del lobo marino común Otaria flavescens durante la época reproductiva. Registramos un total de 44 visitas de embarcaciones a la lobera reproductiva de Isla Chañaral. La mayoría de los turistas mostró una actitud de calma, seguida por moderada y perturbadora. La respuesta de los lobos marinos fue mayoritariamente de escape, seguida de inactiva y alerta. La respuesta de los lobos marinos se relacionó negativamente con la distancia de aproximación de la embarcación a la colonia, pero no se relacionó ni con el tiempo de permanencia de la embarcación en la colonia ni con la conducta de los turistas. Nuestros resultados indican que el lobo marino común es afectado negativamente por la presencia de turistas, especialmente debido al escape de los individuos desde la colonia al mar. Dichos escapes pueden generar efectos fisiológicos negativos sobre el animal, lo que puede incidir sobre su adecuación biológica. Sugerimos que futuros estudios evalúen el comportamiento de respuesta de los lobos marinos durante la época reproductiva y en otros periodos del año, además de analizar posibles diferencias entre clases de edad y sexo, lo que permita contar con herramientas adecuadas para el manejo del turismo sobre el lobo marino común en Chile.
\end{abstract}

Palabras clave: Comportamiento animal, ecoturismo, manejo, pinípedos, Chile

\begin{abstract}
Pinnipeds have a high predictability, both spatial and temporal, and tend to be distributed in patches, which permitting tourists easy access to them. However, the presence of tourists may generate a negative impact on the animals. The objective of this study was to evaluate, for the first time in Chile, the effect of ecotourism activities on the behavior of the South American sea lion Otaria flavescens during the reproductive season. We recorded a total of 44 visiting boats to the reproductive colony of this species on Isla Chañaral. The attitude of the majority of the tourists was a quiet one; however this was followed by moderate and disturbing behavior. The response of sea lions was mainly to escape, followed by a period of inactive and alert. The response of sea lions was negatively related to the distance at which the boats approached the colony, but was not related to the time boats remained in the colony or the behavior of tourists. Our results show that the South American sea lion is negatively affected by human presence, shown by the escape of individuals from the colony to the sea. Escaping from the colony may generate negative physiological effects on an animal physiological effects on an animal, and ultimately affect the fitness of the individual. We suggest that future studies should evaluate changes in behavior during the reproductive season and in other periods, and the behavior of sea lions at different ages and sexes, to provide tools to improve the management of tourist activities on the South American sea lion in Chile.
\end{abstract}

Key words: Animal behavior, ecotourism, management, pinnipeds, Chile

\section{INTRODUCTION}

Ecotourism activities have increased exponentially in recent years all over the world, especially relating to those species which have a high spatial and/or temporal predictability
(Cassini et al. 2004). This is the case for species inhabiting coastal areas, in which the distribution of some occurs in patches, such as nesting areas of marine birds and some 
species of marine mammals, allowing easy access for tourists (Kirkwood et al. 2003). However, although this activity generates important economic input for the local communities, uncontrolled visits may have a negative impact on the species, both at the individual and population level (Barton et al. 1998).

A number of pinniped species (seals, walrus and sea lions) are currently subjected to strong anthropic perturbation, because of both interactions with fishing activities (Wickens 1995, Trites et al. 1997) and ecotourism (Engelhard et al. 2001, Lalas \& Bradshaw 2001). Several responses of sea lions to the presence of tourists have been described, such as an increase in alert behavior (Engelhard et al. 2002), decrease in the time mothers spend with their offspring (Kovacs \& Innes 1990), aggressive behavior of animals towards tourists (Barton et al. 1998, Cassini et al. 2004) and even the escape of animals from the colony (Born et al. 1999, Cassini et al. 2004), which may lead to the abandonment of an area as a reproductive or resting site.

Isla Chañaral is part of an important marine reserve in the north-central area of Chile, attracting hundreds of tourists during the year, especially in summer months. For example, in the summer of 2010 the island was visited by about 1200 tourists, the majority during the month of February (CONAF) ${ }^{1}$. The principal activity of tourists in the reserve is whale watching, due to the diversity of cetacean species which are seen in the area, such as minke whales (Balaenoptera acutorostrata), humpback whales (Megaptera novaeangliae), fin whales (B. physalus), and bottlenose dolphins (Tursiops truncatus) (Capella et al. 1999, Pérez et al. 2006). Tourists also observe a diverse species of birds which nest on the island, such as the Humboldt penguin (Spheniscus humboldtii), Peruvian booby (Sula variegata) and Dominican gull (Larus dominicanus) (Simeone et al. 2003). Additionally, tourists observe the pinniped colonies which inhabit the island, principally the South American sea lion (Otaria flavescens), and to a lesser degree some phocids, such as the southern elephant seal (Mirounga leonina) (Sepúlveda et al. 2007, 2009). In particular, the reproductive colony of the South American sea lion on the island is a great tourist attraction, due to its easy access and to the fact that the peak tourism period coincides with the reproductive period of the species, in which there is a high animal abundance and newborn pups (Acevedo et al. 2003, Pavés et al. 2005, Sepúlveda et al. 2009). Visitors are brought in artisanal boats of about $7 \mathrm{~m}$ in length; they observe from the ocean, since landing on the island is prohibited.

Although in other countries there are laws which limit the approaching distance and the number of visitors to animal colonies, in Chile there is no regulation that restricts tourist visits or a minimum approach distance to animals. A regulation is currently under discussion concerning the observation of aquatic mammals, reptiles and birds which would limit observation distance to a minimum of $50 \mathrm{~m}$ for sea lions; however, it has not yet been approved. Only an ordinance in a few local communities limits the access of tourists to wildlife areas, such as the marine reserve of Punta de Choros in the north-central area and Puñihuil in the south.

Due to the accelerating increase of ecotourism and its potential negative impact on pinniped colonies, it is necessary to quantify the effects of its perturbations on these species. The objective of this study is to evaluate, for the first time in Chile, the effect of ecotourism on the behavior of the South American sea lion.

\section{Materials AND METHODS}

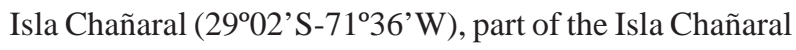
Marine Reserve and the National Humboldt Penguin Reserve, is located in north-central Chile (Fig. 1). The island is about $10 \mathrm{~km}$ from the coast; the sea lion colony is located in the protected zone which extends from the island to the continent. During the summer, this colony is composed of approximately 850 individuals, about $70 \%$ of which are concentrated in the reproductive area of the colony (Sepúlveda et al. 2009). Most of the individuals in the nonreproductive area are sub-adult males, old males and juveniles who do not participate in reproduction.

The field study lasted from 07 to 18 February, 2010. During this period, two observers remained hidden at a height distance of $10 \mathrm{~m}$ above the animals from 0900 to $1800 \mathrm{~h}$. We maintained a daily record of the visiting tourist boats to the colony. For each visit, we recorded: (1) the length of time the boat was close to the colony; (2) the minimum distance between the boat and the colony; (3) the behavior of the tourists; and (4) the behavior of the sea lions. The minimum distance between the boat and the colony was estimated by extrapolating the size of the

${ }^{1}$ Logbook from Corporación Nacional Forestal, Atacama, northern Chile. 


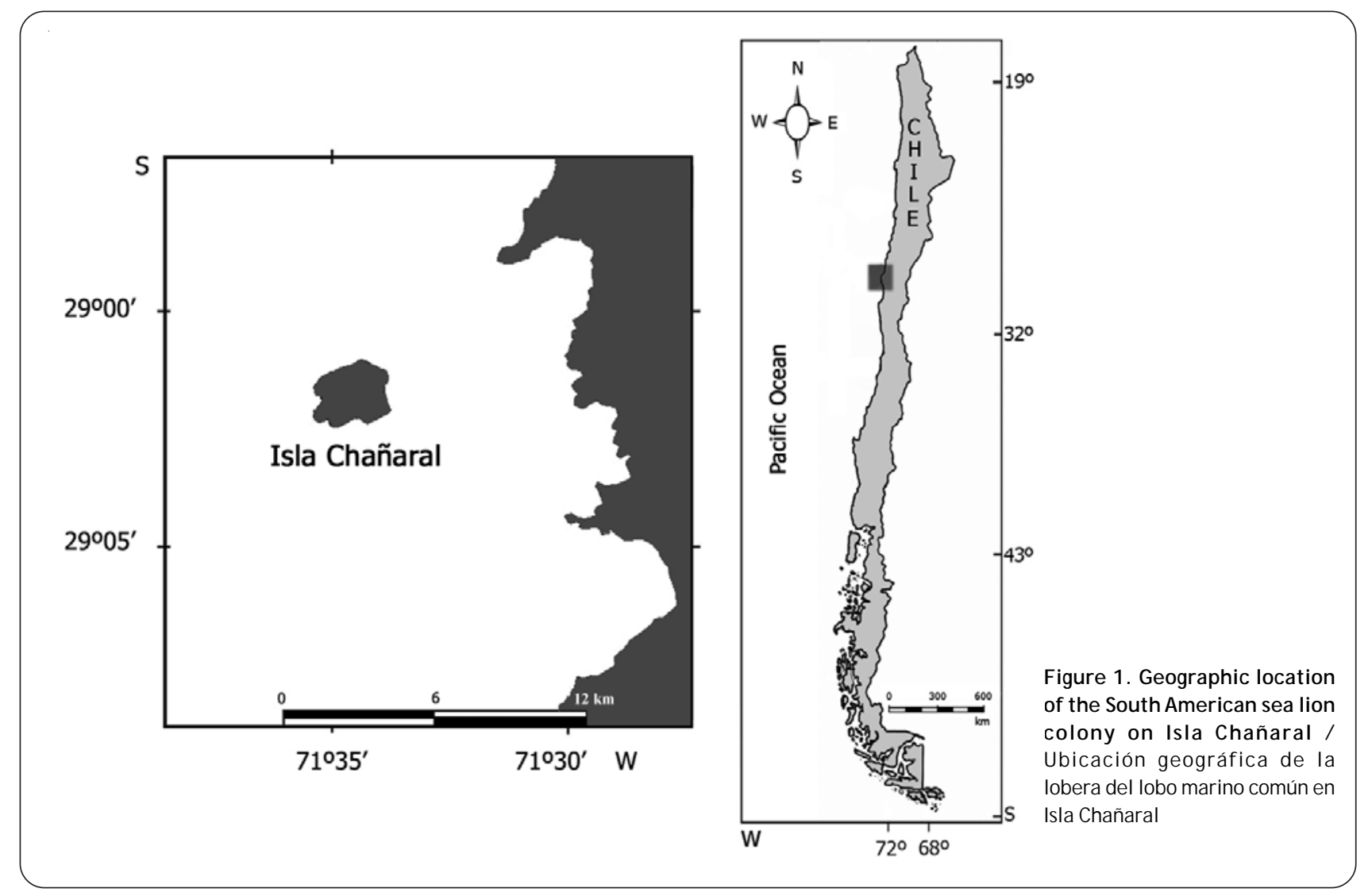

boat ( $7 \mathrm{~m}$ length) to that distance. The types of behavior recorded for tourists and sea lions are shown in Tables 1 and 2, respectively; using similar behavior categories previously described by Cassini et al. (2004). The behavior categories were grouped in an ascending ordinal scale from neutral behavior to negative behavior, both for tourists and for sea lions. The categories for tourists were (0) quiet, (1) moderate and (2) disturbing (Table 1). For sea lions, the categories were (0) inactive, (1) alert, (2) aggressive and (3) escape (Table 2). Categories were assigned based on the overall behavior of the group, i.e., the behavior category which was shown by the majority of the individuals (both for sea lions and tourists). The non-parametric Kruskal-Wallis test was used to evaluate the effects of boat distance and the length of boat stays on sea lion behavior, since the data did not fulfill the requisites for parametric statistics (Zar 1996). The relation between tourist behavior and sea lion behavior was analyzed using a contingency chi-square test. All analyses were performed with the software package Statistica 7.0 (StatSoft Inc. 2004)2.
Table 1. Behavior categories for tourists / Categorías conductuales de los turistas

\begin{tabular}{ll}
\hline Behavior & \multicolumn{1}{c}{ Definition } \\
\hline Quiet & Tourists remain seated, do not talk or speak \\
Moderate & Tourists stand, talk and move. They take photographs with the flash \\
Disturbing & Tourists clap, yell or make brusque movements \\
\hline
\end{tabular}

Table 2. Categories of sea lions responses to tourist visits / Categorías de respuestas de los lobos marinos a la visita de turistas

\begin{tabular}{ll}
\hline Behavior & \multicolumn{1}{c}{ Definition } \\
\hline Inactive & Animals rest normally, do not show behavior related to tourists \\
Alert & Animals lift their head to observe the boat, change position \\
Aggressive & Animals exhibit some sign of aggression towards the boat (e.g., vocalization) \\
Escape & Individuals enter the water due to the presence of tourists \\
\hline
\end{tabular}

${ }^{2}$ StatSoft. 2004. Statistica, Version 7. Statsoft, Inc., Tulsa, OK. 


\section{ResULTS}

We recorded a total of 44 boat visits to the colony during the study period; the mean distance of the closest approach ( $\pm \mathrm{SD}$ ) was $15.2 \pm 9.7 \mathrm{~m}$ (range: 6-50 m); they stayed near the colony for $3.1 \pm 1.5 \mathrm{~min}$ (range: 1-7 min). This reproductive colony was visited by $3.9 \pm 1.6$ boats per day (range: 2-7 visits).

The behavior of the tourists was mostly quiet, followed by moderate and disturbing behavior (Fig. 2a). The response of the sea lions was mainly that of escape, followed by inactive and alert (Fig. 2b). We did not record any instances of aggressive behavior by the sea lions.

The response of the sea lions was not significantly related with the behavior of the tourists $\left(\chi^{2}=4.68\right.$, g.l. $=2$, $P=0.322$ ) or with the length of time the boat stayed near the colony $\left(\mathrm{H}_{(2,37)}=1.891, P=0.388\right)$. However, we found a significant difference between the closest approach of the boat and the behavior of the sea lions $\left(\mathrm{H}_{(2,37)}=6.40, P\right.$ $=0.040)$ (Fig. 3). When boats approached close to the colony the animals showed a more negative response, escaping when boats came closer than $25 \mathrm{~m}$ to the colony.

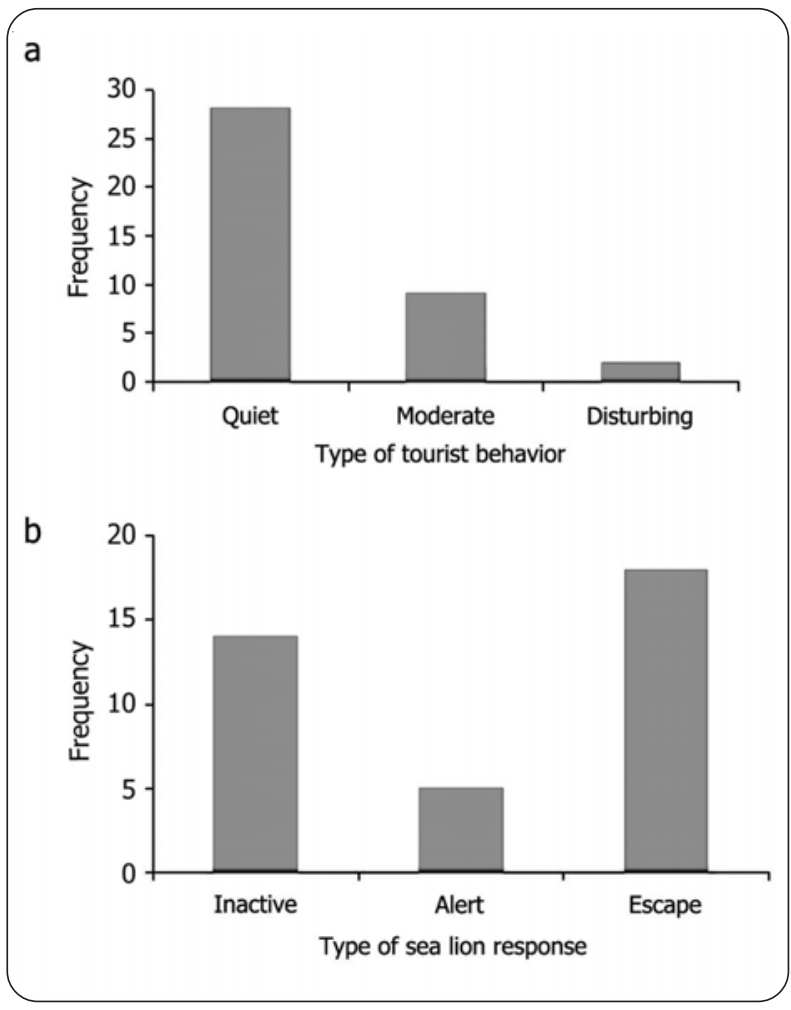

Figure 2. Frequency distributions of a) tourist behavior and b) responses of sea lions to tourists / Distribución de frecuencias de a) conducta de los turistas y b) respuestas de los lobos marinos a los turistas

\section{Discussion}

Along the Chilean coast South American sea lions are frequently seen, and there are several places where one may visit these animals, via a tourism company, local fishermen or privately (Kirkwood et al. 2003). However, there is no record of the effect of tourist activities on the sea lions. Ours is the first study in the country which evaluates this effect on a colony of sea lions during the reproductive season.

We found that a closer approach of a boat to the colony caused individuals to escape from the colony to the sea. Although we did not evaluate if this behavior is negative to the animals, several studies establish that the escape of animals to the water may have negative consequences of a different kind and importance. For example, a direct effect in reproductive colonies is that animals may stampede and thus crush and kill newborn pups (Mattlin 1978). Also, the escape of animals to the water produces an increase in energy expenditure due to loss of body heat, which may generate physiological stress throughout flaws in metabolic regulation (Castellini 2002). Finally, the escape and subsequent abandoning of a site within the colony may affect the reproductive success of the individuals. Males of $O$. flavescens defends territories where females go to mate (Cappozzo 2002); thus escape and subsequent abandoning of the territory will have a direct negative effect on the fitness of these individuals.

Our results coincide with those of other studies which have shown that a negative behavior of pinnipeds increases at shorter distances. For example, it has been shown in harp seals (Pagophilus groenlandicus) that

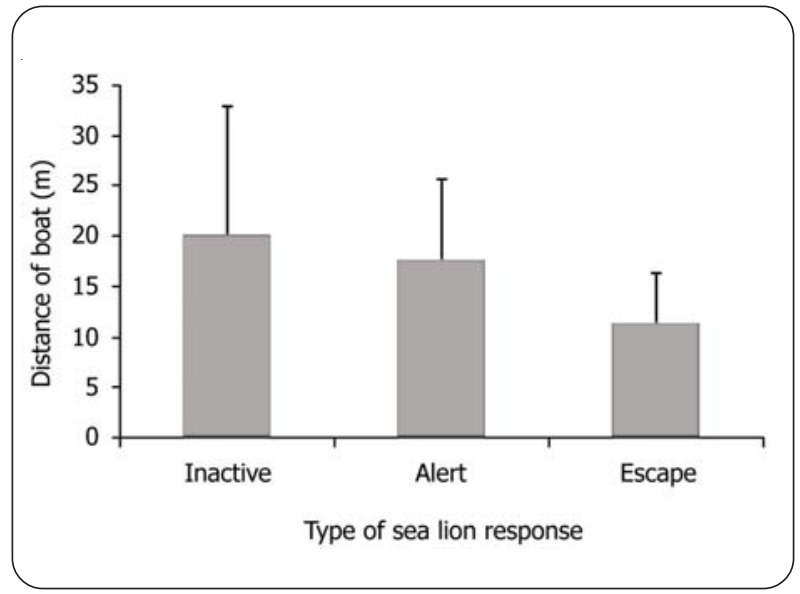

Figure 3. Relationship between the responses of sea lions to tourists and the distance of boat approaches to the colony / Relación entre las respuestas de los lobos marinos a los turistas y la distancia de acercamiento de la embarcación a la colonia 
tourist visits produce an increase in the alert state of the animals, and thus a decrease in the time that mothers care for their offspring and a consequent reduction in the time spent nursing them (Kovacs \& Innes 1990). These same authors found that when tourists came closer than $3 \mathrm{~m}$, females showed aggressive behavior towards their own offspring. For the New Zealand fur seal (Arctocephalus forsteri), Barton et al. (1998) found that when tourists approached within less than $5 \mathrm{~m}$ of the animals they reacted with threatening behavior.

Behavioral assessments of the responses to tourists have been used to determine minimum approaching distances (Cassini et al. 2004). Previous studies on pinnipeds underscore the fact that there appears to be a threshold distance (about $10 \mathrm{~m}$ between tourists and animals) that triggers negative behavioral responses (Kovacs \& Innes 1990, Cassini 2001, Cassini et al. 2004). This study found that sea lions escaped to the ocean when boats came closer than $25 \mathrm{~m}$. Since the approach distance of tourists to pinnipeds is an important variable in the response of the animals, a number of countries have established minimum approach distances. For example, New Zealand law requires a minimum approach of $20 \mathrm{~m}$ to sea lions (Boren et al. 2002); in western Australia the minimum approach distance is $10 \mathrm{~m}$ (Kirkwood et al. 2003), and in the Antarctic a minimum approach distance of 5-10 m has been suggested for seals (IAATO 2007). In Chile, at this moment there is no legislation which establishes an approach limit to the sea lions. However, a regulation is about to be approved which will establish a minimum approach distance of $50 \mathrm{~m}$ for these species. Based on our results, it is expected that once this regulation takes effect, the impact on sea lion populations could decrease.

We consider that future studies should focus on analyzing the response of different sexes and age classes to human perturbation, since there may well be differences among them. For example, Barton et al. (1998) found a differential response between males and females of the New Zealand sea lion to human presence; females responded negatively to perturbation at shorter distances and for less time. In contrast, males defended their territories, with more aggressive responses to tourists at greater distances and for a longer time than females. It is also important to evaluate other factors that may affect the behavior of the animals. Boren et al. (2002) indicated that some specific characteristics of the animals, such as the sex and previous exposition to a perturbation, and some specific factors of the place, such as the way the tourists approached and whether the colony is a reproductive site or a haul-out, may influence the type of response of animals to human activity. This last factor is especially relevant, since this study was performed in the reproductive part of the colony and we did not evaluate what happened in the non-reproductive area. It would also be interesting to evaluate the effect of human perturbation outside the reproductive season, when adult males do not behave territorially and offspring are more independent.

In conclusion, we demonstrated a negative impact of tourist visits to the reproductive colony of Isla Chañaral. We found that the distance of a boat to the colony was the variable which produced the greatest impact on the behavior of the sea lions, generating the escape conduct at shorter distances. This change in the behavior of the sea lions may have a potential effect on the fitness of individuals. However, because this study was done over a short period of time, our results should be taken with caution. Future studies should collect more data, and evaluate the physiological effects of human presence on sea lions, in the reproductive season and in other seasons and among age and sex classes, in order to provide tools which contribute to improving the management of tourist activity in Isla Chañaral.

\section{ACKNOWLEDGMENTS}

We thank Daniela Catalán, Franco Bueno and Priscila Paredes for their help with data collection in the field, Jeanette Santana for bibliographic support, Patricio Ortiz for logistic support in the field and Lafayette Eaton for editing the text. A special thanks to the Corporación Nacional Forestal (CONAF-Atacama) for authorizing the work in the Isla Chañaral, especially to Carla Louit, Pablo Arrospide and José Núñez for logistic support while we were on the island. We also appreciate the information provided by fishermen on the field, Aurelio Aguirre and Fernando Avalos. This study was funded by DIPUV 25/2007. MS acknowledge to MECESUP UVA0604.

\section{LITERATURE CITED}

Acevedo J, A Aguayo-Lobo \& W Sielfeld. 2003. Eventos reproductivos del león marino común, Otaria flavescens (Shaw 1800), en el norte de Chile (Pacífico suroriental). Revista de Biología Marina y Oceanografía 38(2): 69-75.

Barton K, K Booth, J Ward, DG Simmons \& JR Fairweather. 1998. Visitor and New Zealand fur seal interactions along the Kaikoura Coast, 71 pp. Tourism Research and Education Centre Report 9. Lincoln University, Canterbury. 
Boren LJ, NJ Gemmell \& KJ Barton. 2002. Tourist disturbance on New Zealand fur seals Arctocephalus forsteri. Australian Mammalogy 24: 85-95.

Born EW, FF Riget, R Dietz \& D Andriashek. 1999. Escape responses of hauled out ringed seals (Phoca hispida) to aircraft disturbance. Polar Biology 21: 171-178.

Capella J, Y Vilina \& J Gibbons. 1999. Observación de cetáceos en isla Chañaral y nuevos registros para el área de la Reserva Nacional Pingüino de Humboldt, norte de Chile. Estudios Oceanológicos 18: 57-64.

Cappozzo HL. 2002. South American sea lion Otaria flavescens. In: Perrin WF, B Würsig \& JGM Thewissen (eds). Encyclopedia of marine mammals, pp. 1143-1146. Academic Press, San Diego.

Cassini MH. 2001. Behavioural responses of South American fur seals to approach by tourists - a brief report. Applied Animal Behaviour Science 71: 341-346.

Cassini MH, D Szteren \& E Fernández-Juricic. 2004. Fence effects on the behavioural responses of South American fur seals to tourist approaches. Journal of Ethology 22: 127-133.

Castellini M. 2002. Thermoregulation. In: Perrin WF, B Würsig \& JGM Thewissen (eds). Encyclopedia of marine mammals, pp. 1245-1250. Academic Press, San Diego.

Engelhard GH, J van den Hoff, M Broekman, ANJ Baarspul, I Field, HR Burton \& PJH Reijnders. 2001. Mass of weaned elephant seal pups in areas of low and high human presence. Polar Biology 24: 244-251.

Engelhard GH, ANJ Baarspul, M Broekman, JCS Creuwels \& PJH Reijnders. 2002. Human disturbance, nursing behaviour, and lactational pup growth in a declining southern elephant seal (Mirounga leonina) population. Canadian Journal of Zoology 80: 1876-1886.

IAATO. 2007. Marine wildlife watching guidelines (whales, dolphins, seals and seabirds) for vessel and zodiac operations, 8 pp. International Association of Antarctica Tour Operators, Colorado.

Kirkwood R, L Boren, P Shaughnessy, D Szteren, P Mawson, L Hückstädt, G Hofmeyr, H Oosthuizen, A Schiavini, C Campagna \& M Berris. 2003. Pinnipedfocused tourism in the Southern Hemisphere: a review of the industry. In: Gales N, M Hindell \& R Kirkwood (eds). Marine mammals: fisheries, tourism and management issues, pp. 257-276. CSIRO Publishing, Victoria.
Kovacs KM \& S Innes. 1990. The impact of tourism on harp seals (Phoca groenlandica) in the Gulf of St. Lawrence, Canada. Applied Animal Behaviour Science 26: 15-26.

Lalas C \& CJA Bradshaw. 2001. Folklore and chimerical numbers: review of a millennium of interaction between fur seals and humans in the New Zealand region. New Zealand Journal of Marine and Freshwater Research 35: 477-497.

Mattlin RH. 1978. Pup mortality of New Zealand fur seal (Arctocephalus fosteri Lesson). New Zealand Journal of Ecology 1: 138-144.

Pavés HJ, RP Schlatter \& CI Espinoza. 2005. Patrones reproductivos del lobo marino común, Otaria flavescens (Shaw 1800), en el centro-sur de Chile. Revista Chilena de Historia Natural 78: 687-700.

Pérez MJ, F Thomas, F Uribe, M Sepúlveda, M Flores \& R Moraga. 2006. Fin whales (Balaenoptera physalus) feeding on Euphausia mucronata in nearshore waters off north-central Chile. Aquatic Mammals 32(1): 109-113.

Sepúlveda M, MJ Pérez-Álvarez, P López \& R Moraga. 2007. Presence and re-sigthing of southern elephant seal, Mirounga leonina (L. 1758), on the north-central coast of Chile. Latin American Journal of Aquatic Mammals 6(2): 199-202.

Sepúlveda M, P Inostroza, MJ Pérez-Álvarez, D Oliva \& R Moraga. 2009. Seasonal variation in the abundance of South American sea lions Otaria flavescens (Shaw, 1800) in Chañaral Island, Reserva Nacional Pingüino de Humboldt, Chile. Revista de Biología Marina y Oceanografía 44(3): 685-689.

Simeone A, G Luna-Jorquera, M Bernal, S Garthe, F Sepúlveda, R Villablanca, U Ellenberg, M Contreras, J Muñoz \& T Ponce. 2003. Breeding distribution and abundance of seabirds on islands off north-central Chile. Revista Chilena de Historia Natural 76: 323-333.

Trites AW, V Christensen \& D Pauly. 1997. Competition between fisheries and marine mammals for prey primary production in the Pacific Ocean. Journal of the Northwest Atlantic Fishery Science 22: 173-187.

Wickens PA. 1995. A review of operational interactions between pinnipeds and fisheries. FAO Fisheries Technical Paper 346: 1-86.

Zar JH. 1996. Biostatistical analysis, 662 pp. Prentice Hall, Englewood Cliffs.

Received 19 J anuary 2011 and accepted 17 March 2011 